\begin{tabular}{|c|l|}
\hline Title & Water and heat budgets in a coastal lagoon controlled by groundwater outflow to the ocean \\
\hline Author(s) & $\begin{array}{l}\text { Chikita, Kazuhisa A.; Uy ehara, Hiroyuki; A I Mamun, A bdullah; U mgiesser, Georg; I wasaka, Wataru; Hossain, Md } \\
\text { Motal eb; Sakata, Y oshitaka }\end{array}$ \\
\hline Citation & $\begin{array}{l}\text { Limnology, 16(3), 149-157 } \\
\text { https://doi.org/10.1007/310201-015-0449-4 }\end{array}$ \\
\hline Issue Date & 2015-08 \\
\hline Doc URL & http://hdl.handle.net/2115/62584 \\
\hline Rights & The original publication is avail lable at link.springer.com \\
\hline Type & article (author version) \\
\hline File Information & Water and heat budgets of a coastal lagoon controlled.pdf \\
\hline
\end{tabular}

Instructions for use 


\title{
Water and heat budgets of a coastal lagoon controlled by groundwater outflow to the ocean
}

\author{
Kazuhisa A. Chikita ${ }^{1}$, Hiroyuki Uyehara², Abdullah Al Mamun², \\ Francesca De Pascalis ${ }^{3}$, Georg Umgiesser ${ }^{3}$, Wataru Iwasaka ${ }^{2}$, \\ Md Motaleb Hossain ${ }^{2}$, Yoshitaka Sakata ${ }^{1}$
}

1 Faculty of Science, Hokkaido University, Sapporo, 060-0810, Japan

2 Graduate School of Science, Hokkaido University, Sapporo, 060-0810, Japan

3 Institute for Marine Science, Italian National Research Council, 30122 Venice, Italy

*Corresponding author: chikita@mail.sci.hokudai.ac.jp 


\section{Abstract}

Oikamanai Lagoon, one of lagoons in the Tokachi coastal region of Hokkaido, Japan, is a few times per year opened to the ocean by water overflow across the sand bar, which is triggered by rainfall or snowmelt runoffs of inflowing rivers. The water budget calculation for the lagoon under closed condition indicates that the net groundwater output occurs as confined groundwater output, probably to the ocean through the sand bar. The net groundwater output is then balanced mainly by river inflow. For the heat budget of the lagoon, the heat flux by the net groundwater output was estimated as an unknown factor, which was balanced by the heat flux of river inflow and a heat storage change of the lagoon. The two net groundwater outputs from the water and heat budgets exhibit the linear relationship near to the one-to-one correspondence. Hence, two unknown factors, groundwater outflow, $G_{\text {out }}$, and groundwater inflow, $G_{i n}$, were estimated separately. As values averaged over the budget period, $G_{\text {out }}$ and $G_{\text {in }}$ were estimated at $1.04 \mathrm{~m}^{3} \mathrm{~s}^{-1}$ and $0.078 \mathrm{~m}^{3} \mathrm{~s}^{-1}$ (7.5\% of $\left.Q_{\text {Gout }}\right)$, respectively. Thus, the groundwater outflow to the ocean, occupying most of groundwater output, may control the water and material cycles and the water residence time, related to the ecosystem in or around the lagoon.

Keywords Oikamanai Lagoon, water budget, heat budget, confined groundwater outflow, sand bar 


\section{Introduction}

The water residence time of coastal lagoons changes greatly, depending on climate conditions, the back catchment scale, the magnitude and frequency of seawater input, the magnitude of freshwater input, mixing conditions of seawater and freshwater, etc. The residence time, linked to water and material cycles in the lagoons, is an important factor to establish the ecosystem in each coastal lagoon and the surrounding marsh (Tartinville et al., 1997). The water residence time in lagoons has been explored by a hydrodynamic model (De Pascalis et al., 2009), chemical tracers (Mudge et al., 2008) or their coupling (Ferrarin et al., 2009; Rapaglia et al., 2010). Calculating the mass balance of Ra in the Venice Lagoon, Italy, Rapaglia et al. (2010) revealed that the submarine groundwater discharge (SGD) into the lagoon is one order of magnitude larger than the total river input. These studies deal with interactions between the lagoon water and seawater in shallow lagoons anytime open to the sea, which have relatively short water residence time of a week or less. Such lagoons do not exhibit strong density stratification accompanied by an oxygen deficient or anoxic saline layer on the bottom. Two coastal lakes, Lake Abashiri and Lake Harutori, in Hokkaido, Japan, commonly have the lower anoxic saline layer, which is provided by the seawater intrusion during the daily high tide (Abashiri) or the spring tide (Harutori), and subsequently its long residence time under strong density stratification. Chikita et al. (1998) and Chikita (2000) explored the dynamic behaviors 
of the anoxic water accompanied by seawater intrusion and mixing with the upper freshwater.

Fujinawa et al. (2009) and Chikita et al. (2012) pointed out that, as a factor of interactions between the inland, lagoon and sea, a groundwater flow plays an important role in the water and mass budgets of the lagoons. Chikita et al. (2012) showed that, in Oikamanai Lagoon, a coastal lagoon in southeastern Hokkaido, Japan, a confined groundwater outflow to the Pacific Ocean prevails under closed condition. Oikamanai Lagoon and the other four coastal lagoons (42 $31^{\prime}$ to $42^{\circ} 40^{\prime} \mathrm{N}, 143^{\circ} 29^{\prime}$ to $143^{\circ} 37^{\prime} \mathrm{E}$ ) are normally closed by the sand bar, but are intermittently open to the Pacific Ocean by the overflow of lagoon water across the sand bar (Fig. 1). In this study, the water and heat budgets of Oikamanai Lagoon are estimated to know the magnitude of groundwater input and output, and thereby, to understand the water cycle system in the lagoon.

\section{Study area and observations}

Five lagoons in the Tokachi coastal region of southeastern Hokkaido, Japan, are intermittently opened to the Pacific Ocean by water overflow at the lowest point of each sand bar

(Fig. 1 ; Chikita et al., 2012). Each sand bar of the lagoons is grown topographically in the southwest to northeast direction. This suggests that southwestward longshore currents transport and deposit sand grains probably from the Tokachi River or from the erosion of bedrock exposed on the coast by marine waves. Oikamanai Lagoon (surface area, $1.55 \mathrm{~km}^{2}$ at $1.52 \mathrm{~m}$ amsl; above 
mean sea level), one of the coastal lagoons, is opened four to five times per year by increasing water level due to snowmelt and rainfall runoffs of inflowing rivers. However, the opening in mid-July is artificially done by an excavator at the lowest point of the sand bar, in order to pick up rarely large corbicula (Corbicula japonica; shell size, $45 \mathrm{~mm}$ or around). The openings make the lagoon drain more than $90 \%$ in volume within a day (Chikita et al., 2012). The frequency of the openings depends on the drainage area and lagoon water volume, which decide the residence time of lagoon water, related to material cycles and the ecosystem in the lagoon and back marsh.

The Oikamanai Lagoon catchment (area, $105.7 \mathrm{~km}^{2}$ excluding the lagoon surface area) mainly has three sub-catchments, of which the two sub-catchments finally produce a main influent river, the Oikamanai River, to control the lagoon water level or water volume (Fig. 2). The Oikamanai River and the other two small rivers flow into the lagoon, making up the back marsh (3.69 $\mathrm{km}^{2}$ in area) in the east to northwest regions of the lagoon (Fig. 2). The geology in drainage basins of the lagoons is mostly Miocene to Pliocene sedimentary rocks. The records at a meteorological station (AMeDAS at the Taiki town) about $15 \mathrm{~km}$ west-southwest of Oikamanai Lagoon indicate the mean annual precipitation of 1,178 mm (11\% snowfall and $89 \%$ rainfall) and annual mean air temperature of $5.6^{\circ} \mathrm{C}$ in $1989-2010$.

In order to estimate the water and heat budgets of Oikamanai Lagoon, the meteorology was measured at $30 \mathrm{~min}$ intervals at site $\mathrm{M}$ and a meteorological station at the Bisei district $8.8 \mathrm{~km}$ 
southwest of the lagoon, the lagoon water level and surface and bottom temperatures at $30 \mathrm{~min}$ interval at site $\mathrm{L}$, and the river stage and water temperature at 30 min interval at sites R1 and R2 in April - October 2011 (Fig. 2). The time series of river discharge at sites R1 and R2 was obtained by using rating curves between river stage and frequent discharge measurement. Each discharge of the northwestern two streams (Fig. 2) was decided by assuming the runoff rate (discharge divided by the drainage area; $\mathrm{mm} \mathrm{day}^{-1}$ ) to be equal to that at site $\mathrm{R} 1$. Water temperature of the two streams was measured at their merging point (site $\mathrm{T}$ in Fig. 2). The lagoon water level was obtained by two pressure gauges for air pressure and air pressure plus water pressure (HOBO water level logger; Onset Computer, Inc.; ranges of $0-9 \mathrm{~m}$ and $-20-50{ }^{\circ} \mathrm{C}$ and accuracies of $\pm 0.5 \mathrm{~cm}$ and $\pm 0.37{ }^{\circ} \mathrm{C}$ for freshwater depth and temperature, respectively). The hourly data of sea level were provided at the Tokachi Bay $33 \mathrm{~km}$ southwest of Oikamanai Lagoon by the Obihiro District Development and Construction Department, the Hokkaido Regional Development Bureau, Ministry of Land, Infrastructure, Transport and Tourism, Japan. For the calculation of the water and heat budgets, all the data were used as daily mean or diurnal values.

Coastal lagoons in the world, most of which were fluvially incised valleys in the past, typically have a basin shape of relatively deep and narrow thalwegs and spacious shallow area, including the marsh (Ferrarin et al., 2010). This means that a small temporal variation of lagoon level produces large variation of the lagoon area. Hence, in order to accurately calculate a 
temporal change of the water volume of Oikamanai Lagoon, the bathymetric map of high resolution (0.2 m depth interval) at high water level was made up by scanning 85 lines with a GPS echo sounder (model HDS-5 83/200TD, LOWRANCE, Inc.; resolution, $\pm 0.01 \mathrm{~m}$ ) attached to a boat in September and October 2010. Meanwhile, the shoreline of the lagoon was determined by topographic surveys with a theodolite and a portable GPS, and compared with the GIS map of 1/25,000 scale in 2006.

\section{Observational results and discussion}

Figure 3 shows time series of hourly lagoon water level (m amsl; above mean sea level) and total river discharge $\left(\mathrm{m}^{3} \mathrm{~s}^{-1}\right)$, and rainfall $\left(\mathrm{mm} \mathrm{hr}^{-1}\right)$ for 1 April - 27 October 2011. As shown by the abrupt decreases in water level, the lagoon opened to the ocean four times at $2300 \mathrm{~h}$ of 25 April, 1900h of 12 July, 1600h of 7 September, and 1700h of 22 September. The openings of 25 April, 12 July and 7 September finally drained $98.4 \%, 96.4 \%$ and $97.8 \%$, respectively, of the water volume before the openings. During the openings, the lagoon water level varied semi-diurnally following the oceanic tide, but the amplitude of the water level variation gradually decreases by the growth of the sand bar at the outlet. The third opening of 7 September occurred by the relatively large river runoff of 5 September from Typhoon No. 12. The lagoon was once closed on the night of 21 September by the growth of sand bar at the outlet. However, the large 
river runoff of 22 September from Typhoon No. 15 again opened the lagoon to the ocean. The second opening of 12 July was done artificially by an excavator, in order that fishermen picked the rarely large corbicula (40 - 45mm in diameter). The first opening of 25 April was produced by relatively small rainfall runoffs, since the high water level had been provided by the snowmelt runoffs.

The bottom topography of the lagoon exhibited a trace of the incised "valley" extending from the northwestern influent streams (Fig. 4a). The "valley" is connected to the relatively deep regions along the sand bar, suggesting that the sporadic outflow of lagoon water is accompanied by the erosion of bottom sediment. The isopleths of water depth indicate the largest change of surface area at depths of 0.6 to $0.9 \mathrm{~m}$ (or the elevation of 0.62 to $0.92 \mathrm{~m}$ amsl). This is clearly reflected in the relation between the lagoon water level and surface area from the bathymetric map (Fig. 4b).

The salinity under closed condition of the lagoon ranged from 0.033 to $0.67 \%$ by frequent vertical measurements at site $\mathrm{L}$, thus corresponding to the salinity of freshwater (less than $0.5 \%$ ) or around.

\section{Water budget of the lagoon}

In order to quantify the net groundwater output in Oikamanai Lagoon, the water budget of 
the lagoon under closed condition was estimated on the daily base by the following equations.

$$
\Delta V / \Delta t=\Delta h \cdot A / \Delta t=(P-E) \cdot A+R-G
$$

and

$$
G=G_{\text {out }}-G_{\text {in }},
$$

where $\Delta V$ is the change of water volume, $V\left(\mathrm{~m}^{3}\right)$ per time, $\Delta t$ (here, a day), $\Delta h$ is the change of water level, $h(\mathrm{~m})$, per $\Delta t, A$ is the water surface area $\left(\mathrm{m}^{2}\right), P$ is the total precipitation (m day $\left.{ }^{-1}\right)$ onto the water surface over the period, $E$ is the evaporation $\left(\mathrm{m} \mathrm{day}^{-1}\right)$ from the water surface, $R$ is the total river water input $\left(\mathrm{m}^{3}\right.$ day $\left.^{-1}\right), G$ is the net groundwater output $\left(\mathrm{m}^{3}\right.$ day $\left.^{-1}\right)$ to the surrounding marsh and/or to the ocean through the sand bar, which consists of groundwater outflow, $G_{\text {out }}$, and groundwater inflow, $G_{i n}$, as shown by Equation (2). The evaporation, $E$, was calculated by the bulk transfer method as follows (Kondo, 1998):

$$
Q_{E}=-86400 \cdot l\left(\frac{\rho_{a} \varepsilon}{p}\right) \cdot\left(a_{E} u_{5}\right) \cdot\left(e_{z}-e_{0}\right)
$$

and

$$
E=\left(Q_{E} / l\right) / \rho_{w},
$$

where $Q_{E}$ is the latent heat flux $\left(\mathrm{J} \mathrm{m}^{-2}\right.$ day $\left.^{-1}\right), \quad l$ is the vaporization heat $\left(\mathrm{J} \mathrm{kg}^{-1}\right), \rho_{a}$ is the air 
density $\left(=1.2 \mathrm{~kg} \mathrm{~m}^{-3}\right), \varepsilon$ is the ratio of water vapor density to dry air density (=0.622), $a_{E}$ is the dimensionless bulk transfer coefficient for the latent heat flux, $u_{z}$ is the wind speed $\left(\mathrm{m} \mathrm{s}^{-1}\right)$ at the height, $z$, above the water surface, $p$ is the air pressure $(\mathrm{Pa})$ at $z, e_{z}$ is the vapor pressure $(\mathrm{Pa})$ at $z$, $e_{0}$ is the saturated vapor pressure at the water surface temperature, and $\rho_{w}$ is the water density $\left(\mathrm{kg} \mathrm{m}^{-3}\right)$ at the surface temperature. The height of the meteorological measurements at site $\mathrm{M}$ and the Bisei district was near $5 \mathrm{~m}$, i.e., $z=5 \mathrm{~m}$ in Equation (3) (Fig. 2). Then, assuming the atmosphere above the lagoon surface to be neutral, the bulk transfer coefficient, $a_{E}$, is given by $1.24 \times 10^{-3}-1.48 \times 10^{-3}$ at $1 \mathrm{~m} \mathrm{~s}^{-1}<u_{5} \leq 20 \mathrm{~m} \mathrm{~s}^{-1}$ (Kondo, 1998). Here, the mean value of $1.36 \times$ $10^{-3}$ was given. In this study, $R$ is given as the sum of river discharge at sites R1 and R2 and the stream water input into the northwestern marsh (Fig. 2 and Fig. 4b).

The parameters, $\lambda, a_{E}, u_{z}, p, e_{z}, e_{0}$ and $\rho_{w}$ in Equations (3) and (4) are determined from the measurements of air temperature, relative humidity, wind speed and air pressure at site $\mathrm{M}$ and surface water temperature at site L. The vertical salinity measurements at site L under closed condition of the lagoon indicated that the salinity of lagoon water is low at $0.033-0.67 \%$, thus being similar to that of freshwater. Hence, the mass balance of the lagoon for salinity, connected to the water budget of Equation (1), was not here considered.

In Equation (1), the net groundwater output, $G$, is unknown, since the other terms are numerically obtained by the hydrometeorological observations and calculations, and the accurate 
surface area at a certain water level (Fig. 4a). The small magnitude of $\Delta h$, not accompanied by the large change of the surface area, $A$, is needed to improve the estimate of $G$, because the $A$ values are roughly given at $0.2 \mathrm{~m}$ depth interval (Fig. 4a), and thus even the small change of $A$ could produce the relatively large error in the $G$ estimate. Hence, the time period of 18 July -4 September (49 days) at relatively stable water level of $h \sim 1.5 \mathrm{~m}$ amsl and $|\Delta h|<0.2 \mathrm{~m}$ with few rainfalls in Fig. 3 was chosen as that for the water budget.

\section{Heat budget of the lagoon}

Corresponding to Equations (1) and (2) for the water budget, the heat budget of Oikomanai Lagoon under closed condition is given in the following:

$$
\begin{aligned}
\Delta S / \Delta t & =\Delta\left[\int_{0}^{h}\left\{\rho_{w} c_{p} T(z)\right\} \cdot A(z) d z\right] / \Delta t \\
& =\left(R_{n}-Q_{H}-Q_{E}\right) \times A+H_{R}+H_{P}-H_{G}
\end{aligned}
$$

and

$$
H_{G}=H_{\text {Gout }}-H_{\text {Gin }}=\rho_{w} c_{p} G_{\text {out }} T_{\text {Gout }}-\rho_{w} c_{p} G_{\text {in }} T_{\text {Gin }},
$$

where $\Delta S / \Delta t$ is the temporal change of heat storage $\left(\mathrm{J} \mathrm{day}^{-1}\right), c_{p}$ is the specific heat $\left(\mathrm{J} \mathrm{kg}^{-1} \mathrm{~K}^{-1}\right)$ of water at constant pressure, $T$ is the water temperature $(\mathrm{K}), Q_{H}$ is the sensible heat flux $\left(\mathrm{J} \mathrm{m}^{-2}\right.$ day $\left.^{-1}\right), H_{R}$ is the heat flux by river water input $\left(\mathrm{J} \mathrm{day}^{-1}\right), H_{P}$ is the heat flux by rainfall onto the 
lagoon $\left(\mathrm{J} \mathrm{day}^{-1}\right)$, and $H_{G}$ is the heat flux by net groundwater input $\left(\mathrm{J} \mathrm{day}^{-1}\right)$, consisting of the heat flux by groundwater output, $H_{\text {Gout }}$, and that by groundwater input, $H_{G i n} . T_{\text {Gout }}$ and $T_{\text {Gin }}$ are temperatures $(\mathrm{K})$ of outflowing groundwater and inflowing groundwater, respectively. $R_{n}$ in Equation (5) is the net radiation, as given in the following:

$$
R_{n}=K^{*}+L^{*}=(1-\alpha) K \downarrow+L \downarrow-L \uparrow=(1-\alpha) K \downarrow+L \downarrow-\varepsilon \sigma T_{s}^{4}
$$

where $K^{*}$ and $L^{*}$ are the net shortwave and longwave radiations $\left(\mathrm{J} \mathrm{m}^{-2}\right.$ day $\left.{ }^{-1}\right)$, respectively, $\alpha$ is the albedo at water surface, $K \downarrow$ is the downward shortwave radiation, $L \downarrow$ and $L \uparrow$ are the downward and upward longwave radiations, respectively, $\varepsilon$ is the emissivity ( $=0.98$ for water), $\sigma$ is the Stefan-Bolzmann constant $\left(=4.90 \times 10^{-3} \mathrm{~J} \mathrm{~m}^{-2}\right.$ day $\left.{ }^{-1} \mathrm{~K}^{-4}\right)$, and $T_{s}$ is the surface water temperature (K). For the downward shortwave radiation, $K \downarrow$, the data at the meteorological station of the Bisei district were used (URL: http://www.town.taiki.hokkaido.jp/soshiki/kikaku/ kikaku/aerospace.html). The downward longwave radiation, $L \downarrow$ was here numerically obtained by calculating the total effective water vapor amount $(\mathrm{cm})$ and the ratio of observed shortwave radiation to shortwave radiation under clear sky (Kondo, 1998). The albedo, $\alpha$, in Equation (7) was assumed to be constant at 0.06 .

The sensible heat flux, $Q_{H}$, was calculated by the bulk transfer method, being the same as 
that for the latent heat flux, $Q_{E}$, in Equation (3). The equation is then as follows:

$$
Q_{H}=86400 \cdot\left(c \rho_{a} a_{H} u_{5}\right) \cdot\left(T_{s}-T_{5}\right) \quad,
$$

where $\mathrm{c}$ is the specific heat $\left(\mathrm{J} \mathrm{kg}^{-1} \mathrm{~K}^{-1}\right)$ of air at constant pressure, $T_{5}$ is the air temperature $(\mathrm{K})$ at $5 \mathrm{~m}$, and $a_{H}$ is the dimensionless bulk transfer coefficient for the sensible heat flux. Assuming the atmospheric condition to be neutral, the bulk transfer coefficient, $a_{H}$, is nearly equal to $a_{E}$. Thus, $a_{H}$ was here given at $1.36 \times 10^{-3}$, being equal to the $a_{E}$ value.

The heat storage, $S$, of the lagoon in Equation (5) on a certain day in the budget period was calculated by linearly interpolating surface and bottom water temperatures at site $\mathrm{L}$ and the relation between the surface area, $A$, and the water level, $h$, in Fig. 4a. The total heat flux by river water input, $H_{R}$, was numerically obtained by using water temperature and discharge data at sites R1, R2 and T. The heat flux by direct rainfall onto the lagoon, $H_{P}$, was obtained by supposing the rainwater input with the air temperature at site M (Fig. 2). Finally, the uniquely unknown factor, $H_{G}$, in Equation (5) was acquired.

The combination of Equation (6) with Equation (2) yields:

$$
G_{\text {out }}=\frac{H_{G}-\rho_{w} c_{p} T_{\text {Gin }} G}{\rho_{w} c_{p}\left(T_{\text {Gout }}-T_{\text {Gin }}\right)} \quad \text { or } \quad G_{\text {in }}=\frac{H_{G}-\rho_{w} c_{p} T_{\text {Gout }} G}{\rho_{w} c_{p}\left(T_{\text {Gout }}-T_{\text {Gin }}\right)}
$$


Hence, if $T_{\text {Gout }}$ and $T_{G i n}$ are appropriately given, the $G$ and $H_{G}$ values from Equations (1) and (5)

lead us to estimate groundwater outflow, $G_{\text {out }}$, and groundwater inflow, $G_{i n}$.

\section{Calculated results}

The temporal variation of daily mean water level and calculated results for water budget over the budget period are shown in Fig. 5. As pointed out by Chikita et al. (2012), the net groundwater output, $G$ is roughly balance by the total river input, $R$. The temporal change of water storage, $\Delta V / \Delta t$, is also controlled by the river water input, especially during rainfall runoffs of inflowing rivers. Chikita et al. (2012) found out that, under non-rainfalls, the $G$ is proportional to the water level, $h$. This suggests that the net groundwater output prevalently occurs as a confined groundwater outflow, probably to the ocean through a gravelly aquifer at the base of the sand bar (Nakao, 1990). During rainfalls or rainfall runoffs, there exists no linear relationship between $G$ and $h$, as shown in the periods of $18-25$ July and 26 August -3 September. The evaporation from water surface proves to be negligibly small over the budget period. Thus, under closed condition of the lagoon, the water cycle of river inflow vs groundwater outflow could be a deterministic factor for the residence time of lagoon water in non-rainfall periods.

Calculated results for the heat budget is shown in Fig. 6. The thermal terms in Equation (5) 
are expressed in $\mathrm{W} \mathrm{m}^{-2}$, where $\Delta S / \Delta t, H_{R}, H_{G}$ and $H_{P}$ values are divided by the surface area, $A$, at a given water level, $h$ (Fig. 4a). As in the water budget, the heat budget indicates that the heat flux by net groundwater output, $H_{G}$, is balanced mostly by the total heat flux by river water input, $H_{R}$ and the heat storage change, $\Delta S / \Delta t$. Then, $Q_{E}$ and $Q_{H}$ were both negligibly small over the budget period. The net radiation, $R_{n}$, was not so effective for the $H_{G}$ estimate.

Assuming the bottom temperature at site L to be water temperature for the net groundwater output, the net groundwater output, $G_{H}$, is numerically obtained from the $H_{G}$ estimate. A comparison between the $G_{H}$ and $G$ from the water budget is shown in Fig. 7. There is clearly linear relationship between $G_{H}$ and $G$, being near to the one-to-one correspondence. This suggests that most of the net groundwater output occurs as groundwater outflow originating in the lagoon bottom. This supports that the confined groundwater outflow occurs by passing through the gravelly aquifer inside the sand bar. This is because such gravelly deposits are distributed along the sand-bar base in expose to the lagoon bottom (Chikita et al., 2012).

Applying Equation (9) to the estimated $H_{G}$ and $G$, and giving the bottom water temperature at site $\mathrm{L}$ to $T_{\text {Gout }}, G_{\text {out }}$ and $G_{\text {in }}$ are obtained at $1.035 \mathrm{~m}^{3} \mathrm{~s}^{-1}$ and $0.0778 \mathrm{~m}^{3} \mathrm{~s}^{-1}$, averaged over the budget period, respectively (then, $G_{i n} / G_{\text {out }}=0.0752$ ). Then, the bottom water temperature averaged over the budget period was given at $21.1{ }^{\circ} \mathrm{C}$ as $T_{\text {Gout }}$, and $T_{\text {Gin }}$ was assumed to be $19{ }^{\circ} \mathrm{C}$. At $T_{\text {Gout }}=21.1{ }^{\circ} \mathrm{C}$ and $T_{\text {Gin }}=20{ }^{\circ} \mathrm{C}, G_{\text {out }}$ and $G_{\text {in }}$ averaged over the budget period were 
$1.041 \mathrm{~m}^{3} \mathrm{~s}^{-1}$ and $0.0837 \mathrm{~m}^{3} \mathrm{~s}^{-1}$, respectively (then, $G_{\text {in }} / G_{\text {out }}=0.0804$ ). As a result, a condition of $\Delta T_{G}\left(=T_{\text {Gout }}-T_{\text {Gin }}\right) \geqq 1{ }^{\circ} \mathrm{C}$ over the budget period is needed to give $G_{\text {in }} / G_{\text {out }}<0.1$. Similarly, $0 \leqq \Delta T_{G}<1{ }^{\circ} \mathrm{C}$ and $\Delta T_{G}<0{ }^{\circ} \mathrm{C}$ gives $G_{\text {out }} \sim G_{\text {in }}$ in magnitude and $G_{\text {out }}$ or $G_{\text {in }}<0$, respectively, which occur sporadically in the budget period. The condition, $\Delta T_{G} \geqq 1^{\circ} \mathrm{C}$, thus seems to be reasonable. This should be ascertained by a well observation around the lagoon.

\section{Errors in the heat budget calculation}

The calculations of heat and water budgets indicated that the heat flux by river water input,

linked to the heat flux by confined groundwater outflow to the ocean, controls the thermal condition connected to the residence time of lagoon water. Normally, the river discharge includes the error of $5-10 \%$ in itself. The $R$ and $H_{R}$ values thus offer a relatively large error for the $G$ and $H_{G}$ estimates. As the other errors, the following thermal items are considered.

(1) A topographic screening effect on the downward shortwave radiation, $K \downarrow$ :

The data of the Bisei meteorological station were applied for calculating the downward shortwave radiation, $K \downarrow$ in Equation (7) (Fig. 6). The Bisei station is located at a completely open place, thus not surrounded by any topographic relief. However, the Oikamanai Lagoon has some topographic reliefs in the surroundings (Fig. 2). Such a topographic screening effect on the $K \downarrow$ could then occur by changing the timing of sunrise and sunset or shortening the 
daytime hours. For the daily declinations of the sun in the budget period, the downward shortwave radiation under clear sky, $K_{f} \downarrow\left(\mathrm{J} \mathrm{m}^{-2}\right.$ day $\left.^{-1}\right)$, was calculated by using the hour angles of sunrise - sun's culmination - sunset at the center of the lagoon and those at an open place (Kondo, 1998). As a result, the elevation angle of the surrounding reliefs at the center of the lagoon was less than $1.5^{\circ}$, and the $K_{f} \downarrow$ values were by less than $0.1 \%$ different between the lagoon's center and open place. Thus, the application of the Bisei data to the $K \downarrow$ in Equation (7) seems to be reasonable.

(2) Spatial and temporal changes of water temperature in the lagoon:

For the calculations of $L \uparrow, Q_{E}$ and $Q_{H}$ in Equation (7) and $\Delta S / \Delta t$ in Equation (5), water temperature at site $\mathrm{L}$ were used. The effect of river water input on the water and heat budgets is predominant (Fig. 5 and Fig. 6). Hence, the spatial and temporal changes of water temperature in the lagoon by river inflow should be taken into account. Here, such changes were simulated by a two-dimensional finite element model, SHYFEM, developed by the Institute for Marine Science, National Research Council (ISMAR-CNR), Venice, Italy, where the best fit to the observed temperatures at site L was obtained (Umgiesser et al., 2004; Mamun, 2013). As a result, the spatial change of water temperature, $\Delta T$, on a certain day in May - October 2011 was estimated at $|\Delta T| \leqq 1{ }^{\circ} \mathrm{C}$. Giving the maximum spatial change of $\pm 1^{\circ} \mathrm{C}$, the recalculation of the heat budget offered the error of $4.0-5.7 \%$ for the $H_{G}$ values. 
Thus, due to the spatial change of water temperature, the heat budget calculation proves to

include larger errors than those in the water budget calculation.

\section{Conclusions}

The Oikamanai Lagoon, a coastal lagoon in southeastern Hokkaido, Japan, produces the sporadic water outflow to the Pacific Ocean by partially breaking the sand bar. The water cycle system of the lagoon under closed condition was clarified by exploring the hydrological and thermal conditions of the lagoon. The estimate of the water budget at almost constant water level indicated that the net groundwater output in the lagoon plays the important role on the water budget of the lagoon. Chikita et al. (2012) showed that the net groundwater output occurs mostly as a confined groundwater outflow to the Pacific Ocean across the sand bar. The calculations of the water and heat budgets indicate that the groundwater outflow is an order of magnitude larger than the groundwater inflow. Thus, it is found out that the water and material cycles in the lagoon under closed condition are established mostly by the balance between river inflow and confined groundwater outflow. It is suggested that, at the base of the sand bar, there exists a gravelly confined aquifer as tsunami deposits (Nakao, 1990; Chikita et al., 2012). An underground survey for the sand bar will give us an evidence that the gravelly deposits act as a confined aquifer. 


\section{Acknowledgements}

We are indebted to the Government of the Taiki-city and Fishermen's Union at Hama-Taiki Village for the kind permission of our field observations in the Oikamanai Lagoon. Messrs. Yasuhiro Ochiai and Takuto Miyamoto, staffs of Laboratory of Physical Hydrology, Hokkaido University, helped us carry out our filed observations. We would like to express our gratitude for their great help. This study was supported partly by the Grant for Joint Research Program of the Institute of Low Temperature Science, Hokkaido University.

\section{References}

Chikita KA (2000) Dynamic behaviours of anoxic saline water in Lake Abashiri, Hokkaido, Japan. Hydrological Processes 14: 557-574

Chikita K, Sakamoto H, Fukuyama R, Suzuki M, Sekine J, Nakamichi K, Aikawa C, Hmaguchi K (1998) Dynamic behaviors of “dead water” in a conastal lagoon, Lake Harutori, Kushiro, Hokkaido. Jour Kushiro-city Museum 22: 1-8

Chikita KA, Iwasaka W, Mamun AA, Ohmori K, Itoh Y (2012) The role of groundwater outflow in the water cycle of a coastal lagoon sporadically opening to the ocean. Jour Hydrol 464-465: 423-430 
De Pascalis F, Umgiesser G, Alemanno S, Basset A (2009) Numerical model study in Alimini Lake (Apulia Italy). Geo-Eco-Marina 15: 21-28

Ferrarin C, Umgiesser G, Scroccaro I, and Matassi G (2009) Hydrodynamic modeling of the Lagoons of Marano and Grado, Italy. Geo-Eco-Marina 15: 13-19

Ferrarin C, Cucco A, Umgiesser G, Bellafiore D, Amos CL (2010) Modelling fluxes of water and sediment between Venice lagoon and the sea. Continental Shelf Research 30: 904-914

Fujinawa K, Iba T, Fujihara Y, Watanabe T (2009) Modeling interaction of fluid and salt in an aquifer/lagoon system. Ground Water 47: 35-48

Kondo J (1998) Meteorology in Aquatic Environments. $2^{\text {nd }}$ edition, Asakura Publication, Inc., Tokyo, 350pp.

Mamun AA (2013) Hydrodynamics of a coastal lagoon producing groundwater flow into the ocean. MS thesis, Faculty of Science, Hokkaido University, 28pp.

Mudge SM, Icely JD, Newton A (2008) Residence times in a hypersaline lagoon: Using salinity as a tracer. Estuarine, Coastal and Shelf Science 77: 278-284

Nakao K (1990) Hydrological evaluation of breaking frequency of coastal lakes dammed by a sand bar and environmental changes of Lake Oikamanai-numa and Lake Horokayanto-numa, Tokachi, Hokkaido. Mem Geol Soc Jpn 36: 89-102

Rapaglia J, Ferrarin J, Zaggia L, Moore WS, Umgiesser G, Garcia-Solsona E, Garcia-Orellana J, 
Masque P (2010) Investigation of residence time and groundwater flux in Venice Lagoon:

Comparing radium isotope and hydrodynamical models. Journal of Environmental

Radioactivity 101: 571-581

Tartinville B, Deleersnijder E, Rancher J (1997) The water residence time in the Mururoa atoll

lagoon: sensitivity analysis of a three-dimensional model. Coral Reefs 16: 193-203

Umgiesser G, Canu DM, Cucco A, Solidoro C (2004) A finite element model for the Venice

Lagoon. Development, set up, calibration and validation. J Mar Sys 51: 123-145 


\section{Figure Legend}

Fig. 1 Location of coastal lagoons in the Tokachi region of southeastern Hokkaido, Japan

Fig. 2 Location of observation sites in the DEM map of the Oikamanai Lagoon catchment

Fig. 3 Hourly time series of lagoon water level, total river discharge and rainfall at site $\mathrm{M}$ in April - October 2011. An arrow in the upper shows a time period (18 July - 4 September) for calculating water and heat budgets

Fig. 4 (a) relation between water level (m asl) and surface area $\left(\mathrm{km}^{2}\right)$ at $0.2 \mathrm{~m}$ depth interval, and (b) bathymetry at $1.52 \mathrm{~m}$ amsl (0.3 $\mathrm{m}$ depth interval) for Oikamanai Lagoon

Fig. 5 Daily time series of calculated hydrological terms in Equation (1) and observed lagoon water level

Fig. 6 Daily time series of calculated thermal terms in Equation (5)

Fig. 7 Relation between the net groundwater output, $G$, from the water budget and the net 
groundwater output, $G_{H}$, from the heat budget 


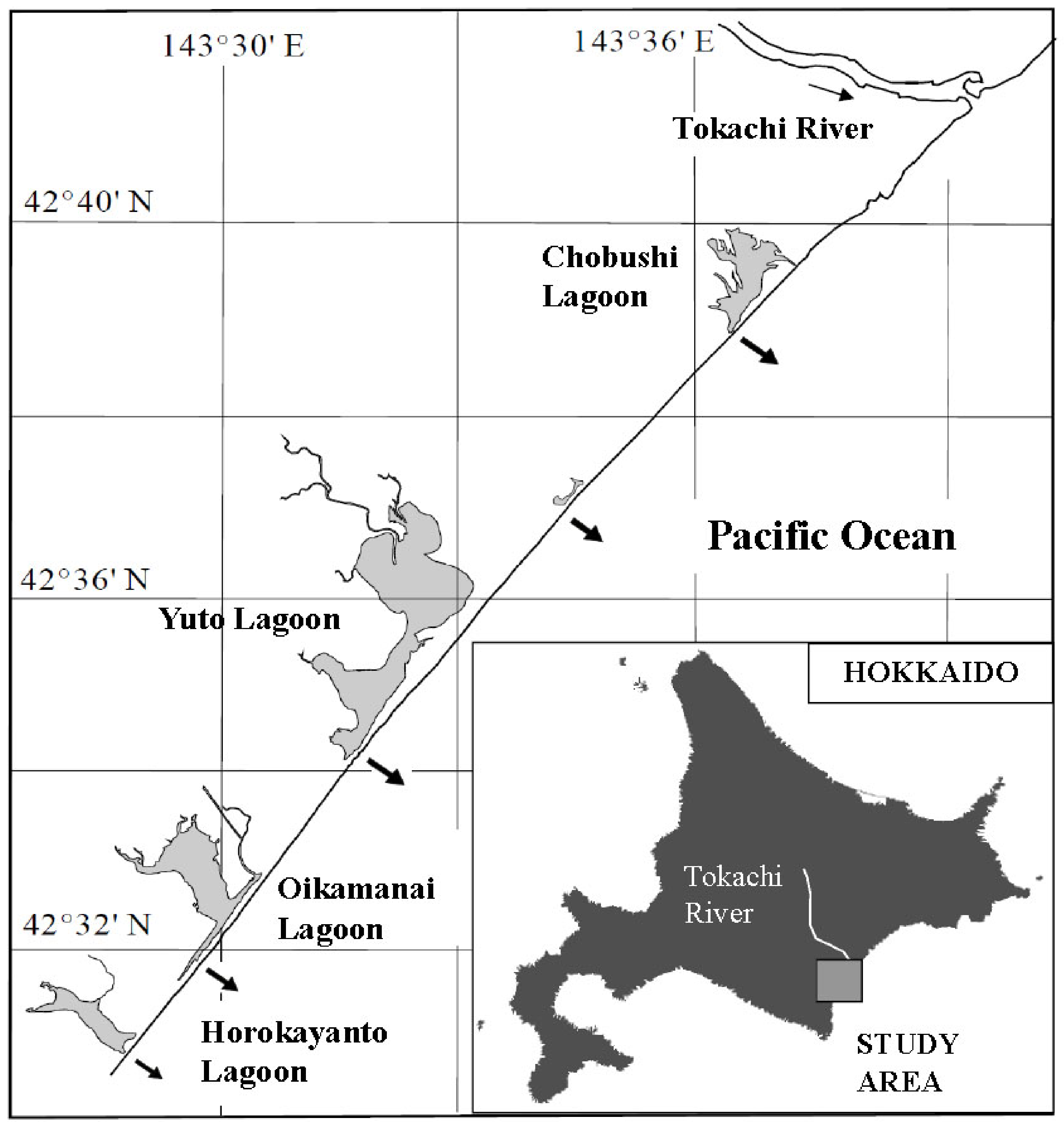




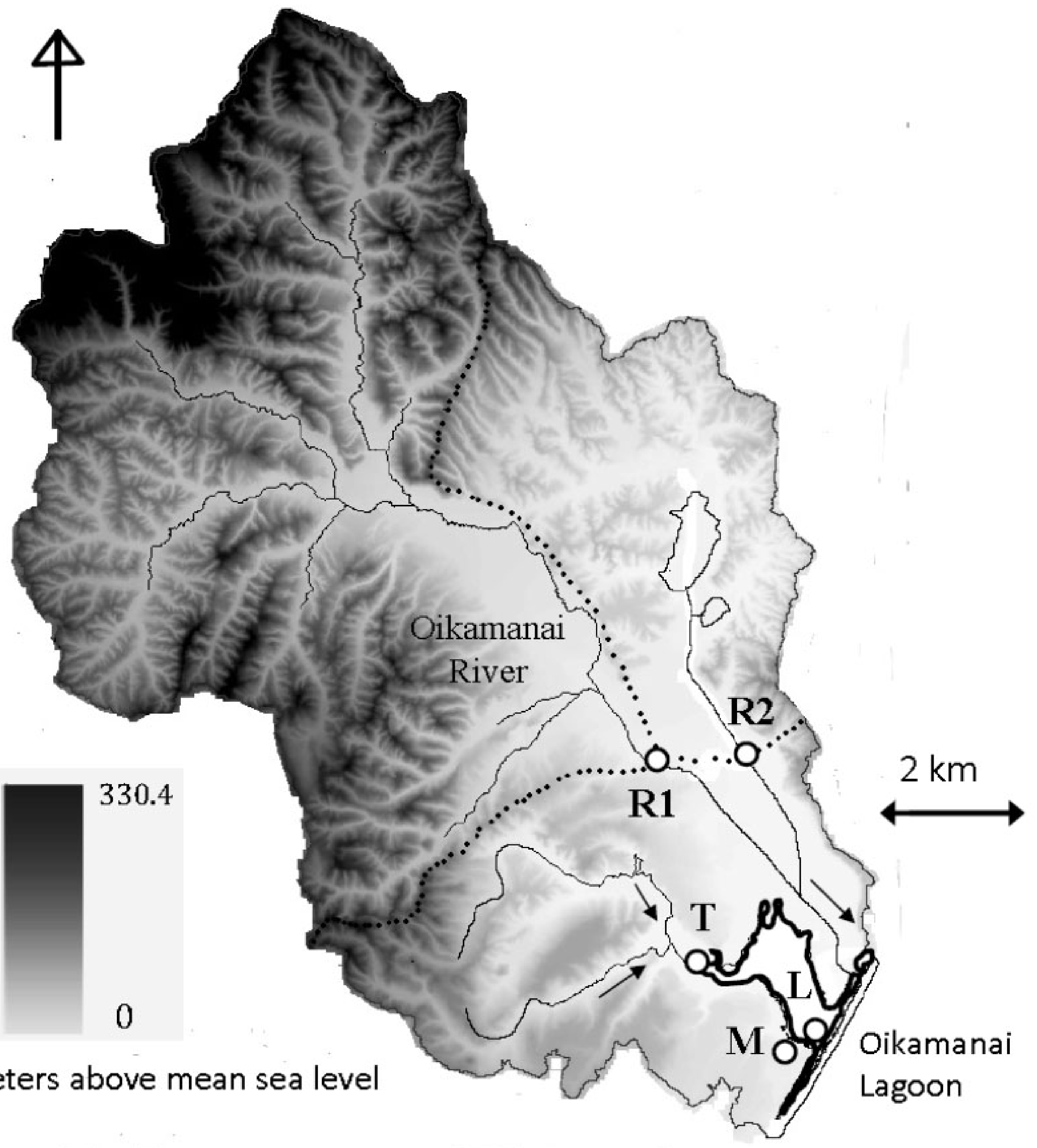


(a)

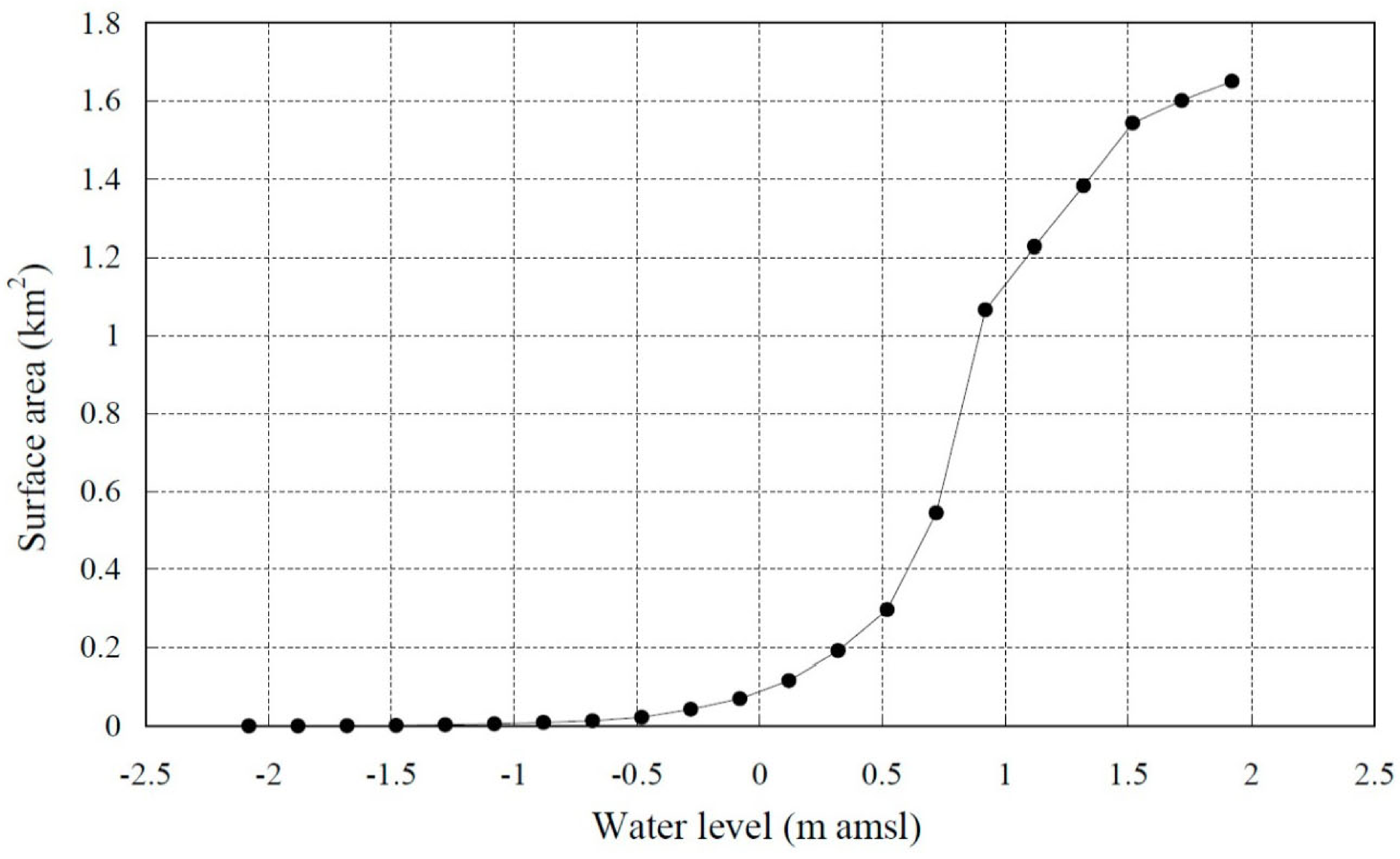

(b)

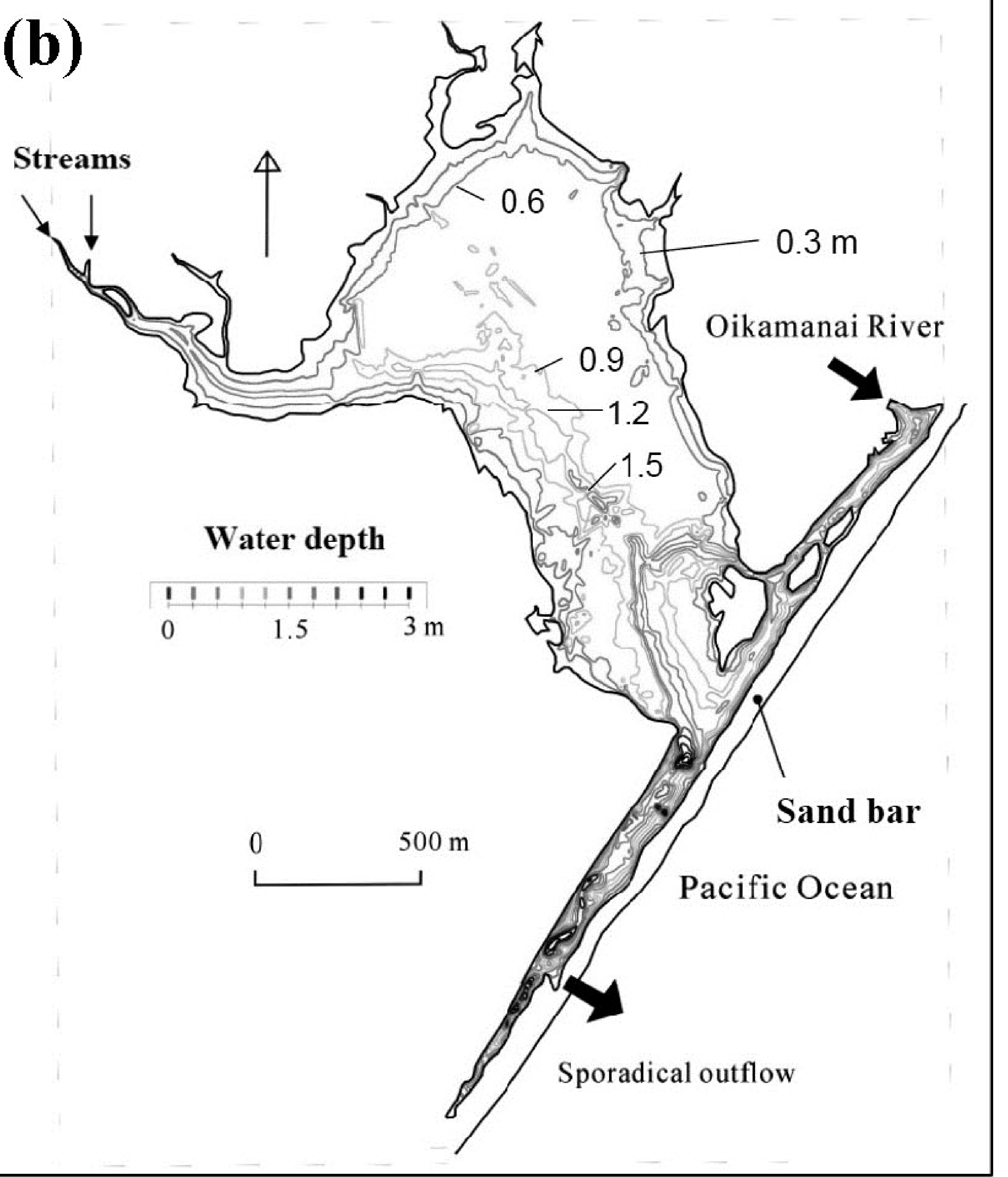


